\title{
Q FEVER EPIDEMIOLOGY AND CONTROL IN DOMESTIC ANIMALS
}

\author{
Vidić Branka ${ }^{1}$, Zorica Šeguljev ${ }^{2}$, Savić Sara ${ }^{1}$, Prica Nadežda ${ }^{1}$ \\ ${ }^{1}$ Scientific Veterinary Institute „Novi Sad" Novi Sad, R. Serbia \\ ${ }^{2}$ Institute of Public Health of Vojvodina, Novi Sad, R. Serbia
}

\section{Abstract}

The significance of each domestic animal in the epidemiology of Q-fever is different in various regions and it depends on the number of animals, level of infection, herd size, type of breeding and the conditions of hygiene. Epizootiological studies in our country show greater prevalence in sheep, than in cattle. Q-fever is maintained in Vojvodina in endemo-epidemic form. In Q-fever management programs for control of in sheep and cattle, serological examination and vaccination of the animals is recommended. Efficiency of the application of these measures should be conducted by applying recommended serological tests and detection of causative agent should be done by PCR method. A study on the comparative examination of efficiency, of different vaccination protocols has not yet been conducted. This would refer primarily to the duration of vaccination program, animal categories that are supposed to be vaccinated and timing for vaccination. A significant decrease in the level of infection was found after vaccination during the first years upon application of vaccination program. When vaccination in heifers was done before pregnancy with vaccines containing $C$. burnetii phase I strains, it was five times less likely that the infection would occur. Vaccination of cows with chronic infection prevents shedding of riketsia via milk, regardless whether the shedding is constant or intermittent. Vaccination represents a new concept of suppression of this zoonozes in the terms of human protection, and also in the terms of creating areas free from Q-fever in endemic regions. General preventive measures applied in the case of Q-fever infection are: movement restriction, separation of ani-

${ }^{1}$ PhD Branka Vidić, principal research fellow; PhD Sara Savić, research fellow, Prica Nadežda, spec.hem, Scientific Veterinary Institute, Novi Sad, Rumenacki put 20, 21000 Novi Sad, Serbia, branka@niv.ns.ac.rs

${ }^{2} \mathrm{PhD}$ Zorica Seguljev, professor, Institute of Public Health of Vojvodina, Novi Sad, R. Serbia 
mals, restriction of milk and wool, adequate hygiene, using the protective clothing, desinfection of equipement and vechicles, removing of placenta particles, removing of manure, quarantine after calving and lambing and not use common grazing. People proffesionally exposed to the risk from infection should be educated about the disease.

Key words: Q-fever, control, vactination, sheep, cattle

\title{
EPIDEMIOLOGIJA I MERE KONTROLE Q-GROZNICE KOD DOMAĆIH ŽIVOTINJA
}

\author{
Vidić Branka ${ }^{1}$, Zorica Šeguljev ${ }^{2}$, Savić Sara $^{1}$, Prica Nadežda $^{1}$
}

\section{Kratak sadržaj}

Značaj pojedinih vrsta domaćih životinja u epidemiologiji Q-groznice je različit u pojedinim područjima a zavisi od njihove brojnosti stepene zaraženosti, veličine stada, načina uzgoja i zoohigijene. Epizootiološka ispitivanja u našoj zemlji ukazuju na veću prokuženost ovaca nego goveda. Q-groznica se u Vojvodini održava endemoepidemiski. U programu kontrole protiv Q-groznice kod goveda i ovaca predlaže se serološka ispitivanja i vakcinacija životinja. Efikasnost primene ovih mera treba sprovoditi primenom preporučenih seroloških testova, a dokazivanje uzročnika PCR metodom.Međutim, uporedno ispitivanje efikasnosti različitih protokola vakcinacije nije istraženo. To se pre svega odnosi na trajanje programa vakcinacije, koje kategorije životinja i kada treba da budu vakcinisane. Primenom vakcinacije uočeno je značajan pad stepena zaraženosti u prvim godinama primene programa vakcinacije. Primena vakcine od sojeva C.burneti faze I, konstatovano je da je vakcinacija junica pre graviditeta imala pet puta manju verovatnoću da će se zaraziti nego gravidne jedinke. Vakcinacija hronično inficiranih krava sprečava izlučivanje rikecija preko mleka, bilo da se radi o konstantnom ili intermitentnom izlučivanju. Primena vakcinacije dala je novi koncept suzbijanja ove zoonoze ne samo u smislu zaštite ljudi, već i u pravcu stvaranja područja slobodnih od Q-groznice u endemskim regionima Od opštih preventivnih mera primenjuje se: zabrana kretanja,

\footnotetext{
${ }^{1} \mathrm{PhD}$ Branka Vidić, principal research fellow; PhD Sara Savić, research fellow, Prica Nadežda, spec.hem, Scientific Veterinary Institute, Novi Sad, Rumenacki put 20, 21000 Novi Sad, Serbia, branka@niv.ns.ac.rs

2 PhD Zorica Seguljev, professor, Institute of Public Health of Vojvodina, Novi Sad, R. Serbia
} 
razdvajanje životinja, zabrana korišćenja mleka i vune, adekvatna higijna, nošenje zaštitne odeće, dezinfekcija opreme i vozila, uklanjanje delova posteljice, adekvatno uklanjanje stajnjaka, karantin kod teljenja i jagnjenja i ne koristiti zajedničku ispašu. Osobe profesionalno izložene riziku potrebno je da prođu obuku i da se edukuju o prirodi oboljenja.

Ključne reči: Q-groznica, mere kontrole, vakcinacija, ovce, krave

\section{INTRODUCTION}

Q-fever is an infectious disease which is the most common of all rickettsia caused diseases in the world and also in our country $(2,4,8,10,12)$. This antropozoonozes is characterized with a wide spectrum of hosts and vectors. Primary role of domestic animals is as reservoirs for the infection of humans and therefore it is very important to precisely and in time Q-fever is detected in domestic animals $(3,5,6,17)$. C. burnetii is one of the most resistant of all unsporalizing microorganisms. In tick feces, it can last for 586 days, in dried blood at room temperature it can last for 5 months, in dust 120 days in wool 12-16 months at 4-6 C, and in milk more than 30 days (13).

Sanitation of endemic foci of Q-fever is practically pretty close to impossible because of the high resistance of the causative agent of Q-fever, a small infectious dosage and various epidemiologies. Spreading of the disease via ticks as vectors is not significant, but inhalation of the causative cause together with the dust is. For development of an infection in domestic animals, a primary cycle in the nature is important. Positive reactors are found in sheep, cattle goats, swine, horses, poultry and cats $(4,9,14,25)$. From clinical point of view, $\mathrm{Q}$ fever is not a negligible issue in veterinary medicine. The miscarriages have been registered, primarily in the sheep, cattle and goats, but also other reproductive disturbances are present, mastitis, poorly viable offspring, etc. $(19,20$, 22). The significance of some domestic animals in epidemiology of Q-fever is different in certain regions and it depends on their number, level of infection, size of the herd, way of breeding and zoo hygiene. The epidemic movement of the Q-fever disease is influenced by other factors such as air flow, rainfall, and density of population and geological characteristics of the terrain $(17,24)$.

Alimentary infections are far less significant compared to the airborne infections (16). The cause of these infections is usually contaminated milk and milk products. Among all food, milk carries the biggest risk of infection. Milk pasteurization is a prophylactic measure for excluding every possible risk of infection for humans.

The problem of prevention from Q-fever is in the lack of specific protection measures and poor efficiency of general preventive measures. Habits of the 
farmer's established long time ago are difficult to change. The basic factors that have negative influence to epidemiologic situation of Q-fever are high level of positive reactors among sheep, nomad way of farming and usage of pastures in sheep breeding.

\section{Situation in AP Vojvodina}

Epizootiological study in our country shows that the prevalence in sheep is higher than the prevalence in cattle $(11,17,21)$. Nomad farming has a special significance in the occurrences of epidemics. In Vojvodina, Q-fever is being maintained endemoepidemicaly $(15,17)$.

Results after a study on the presence of Q-fever on cattle farms in Vojvodina show a significant presence $(9,5 \%)$, while in certain farms the percentage of seroreactors is even over $30 \%(9,14,25)$. The highest percentage of seropositive findings was detected in cows which had miscarriages $(19,4 \%)$, and the lowest was found in animals from endemic regions $(4,8 \%)(19,20)$. The results from serological analysis of workers at cattle farms with enzootics of $Q$ fever show the presence of high level of risk from the infection with C.burnetii, although none of the seropositive workers did not report that he or she was ill from Q fever. Since Vojvodina is an endemic region for Q fever, risk level was analyzed from the infection among users of the raw milk in Vojvodina population (16). A significant difference was not found between the rate of infection in raw milk users $(10,81 \%)$, compared to the rate of infection in the rest of the population $(9,16 \%)$. There are literature data on epidemics of $Q$ fever among cattle farm workers, where the infections were in mild form or without clinical symptoms of the disease $(2,13,16)$. The significance of sheep in the epidemiology of Q fever in Vojvodina is analyzed based on a topographic distribution of registered cases of Q fever in humans, results of serological analysis of 1340 sheep blood samples and 1398 blood samples from the residents of villages. Measured with the percent of positive reactors, sheep from individual economies (sector) have a greater epidemiological significance. Seroprevalence in the sheep from individual sector $(13,8 \%)$ is significantly higher compared to the seroprevalence in the sheep from farms $9,9 \%(X=4,593)$. A statistically significant $(X=94,287)$ higher percentage of seropositive animals was found in the regions where $\mathrm{Q}$ fever epidemics were registered $(31,3 \%)$, compared to the seroprevalence of sheep in other regions $(8,3 \%)$. The significance of sheep in the epidemiology of $Q$ fever is confirmed by a significantly higher $(X=16,606)$ seroprevalence in village residents $(20,3 \%)$, who are professionally or in some other way in contact with sheep, compared to the residents without the con- 
tact with sheep $(12,3 \%)$. Sheep using pasture have a greater epidemiological significance. Seroprevalence in the neighbors of the owners that take their sheep to the pasture $(28,1 \%)$ is higher than in the owners of stable breeding sheep $(11,1 \%)$. The difference is highly significant $(X=15,038)$. In the group of zooantroponoses, Q fever takes a leading position in the region of Vojovdina $(17,221,24)$. The number of reported cases of Q fever in humans in Vojvodina is $95 \%$ of all reported cases in Serbia as whole (15). This is why Q fever is considered to be a specific problem of this province.

Graph 1 - Incidence of Q fever in Vojvodina during the period from 1966-2012*

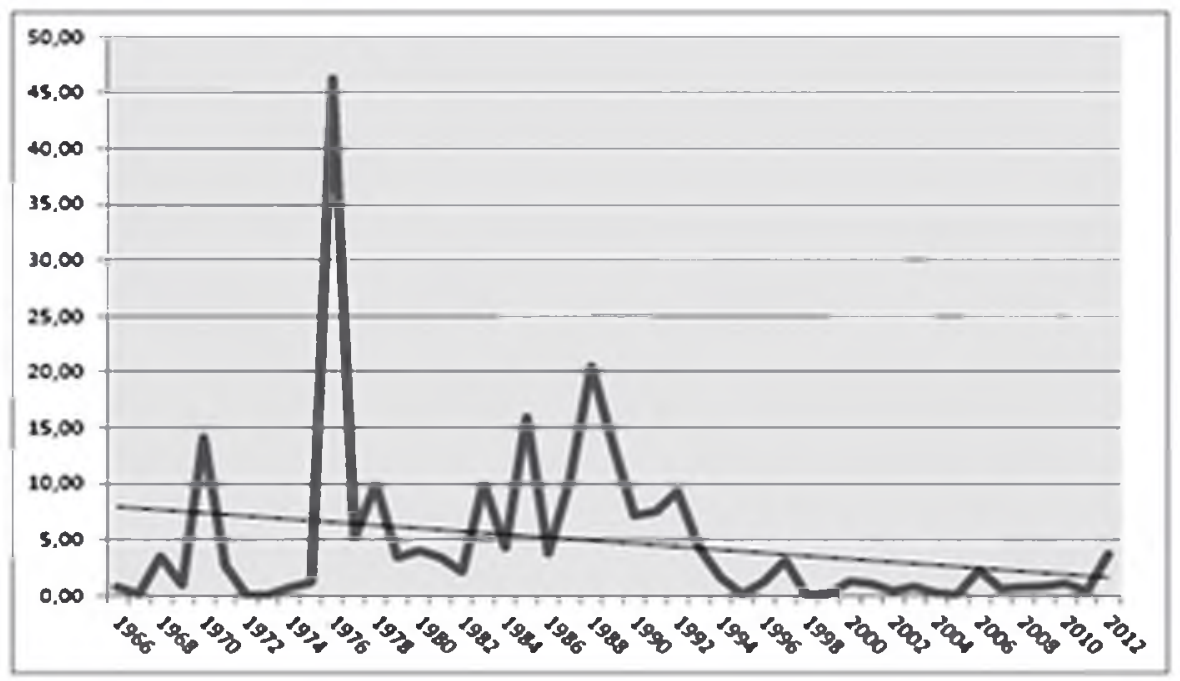

* Institute for public health of Vojvodina: Infectiousdiseases in AP Vojvodina, 2012.

Up to the beggining of 90-es Q fever was a leading zoonozes in Vojvodina. From 1983-1992. an average incidence for Q fever was 10,2/100.000, rangeing from 3,8-20,4/100.000 (15). Large epidemics of Q fever followed the line of nomad sheep flocks movement. Since sheep are the main reservoir of the disease, $Q$ fever was seasonal with about $90 \%$ patiens at the end of winter and beggining of the spring, during the lambing season(15). Since 1991. the number of $Q$ fever patients has significantely decreased. What was mainly caused by the abssence of nomad flocks from other regions of Former Yugoslavia. During the last ten years, the incidence is $0,82 / 100.000$. Q fever can now be seen as small family epidemics among domestic animal owners and it does 
not have a seasonal character any more. The disease has kept a characteristic demographic distribution with a highest specific incidence for productive population and males. More frequently the disease is found in males because of the higher rate of exposure, but also because of the difference in clinical manifestation of the disease. A study was done on 323 patients with acute infection and it was determined that asymptomatic infections were significantly more frequent in female patients $(14,0 \%)$ then in male patients $(4,3 \%)(15,17)$. In a study on the prevelance level for C. burnetii in population of AP Vojvodina in the middle 80es, the difference between the level of prevelance in different genders was not found $(9,4 \%$ for males and $9,3 \%$ for females), while the average incidence for Q fever in males was 2,6 times higher (12,3/100.000) compared to the females $(4,8 / 100.000)(15,17)$. Even when the incidence is significantly reduced, the number of male patients $(1,10 / 100.000)$ is 2 times higher compared to females $(0,55 / 100.000)$

\section{CONTROL}

General preventive measures give insufficient results in suppression and prevention of Q fever infection and specific prevention has no adequate solutions in the whole world. Great resistance of Coxiella in the environment and different epidemiology lead to almost impossible sanitation of endemic focus. Within the control program against $\mathrm{Q}$ fever the most frequently suggested measures are serological examination and vaccination of animals $(2,13,23)$. One of the measures is removing of positive reactors from the flock and in other animals constant control is needed and separation of seropositive animals. Milk from seropositive cows must be pasteurized. Several authors have determined positive effects after vaccination in infected and non infected animals.

$Q$ fever control in cattle is of a great significance, because of the presence of reproductive failures and because they are a significant source of infection and environment contamination $(2,12,13,18,23)$. In practice, vaccination is recommended in infected herds and flocks, but a study on efficiency of different vaccination protocols has not been done, which is related to length of vaccination program, which categories of animals should be vaccinated and when(18). The latest research show good results on the level of single animal and on the level of flock or herd. Analyzed parameters were excretion of the causative agent, contamination of the environment and health status of the animals with a most important aim to determine measures for prevention and suppression of the infection. After application of vaccination a significant decrease of infection level was found during the first years of the vaccination 
program application, with remark that this period should be prolonged. As a key factor to the success, vaccination should be done not only for a short period of time. During the first year of vaccination there is a reduction of clinical symptoms (abortions, infertility), but vaccination period of 3-4 years is necessary in order to stop the shedding of bacteria. Vaccination program for cows and heifer is considered more efficient then program only for heifers. After application of vaccine C.burnetii phase I, heifers vaccinated before pregnancy have five times less probability of getting the infection then already pregnant cows $(1,2,13,18)$. These results justify the application of the vaccination programs for animals in non infected herds and heifers before pregnancy. Besides, vaccination of cows should be done when the level of seroprevalence is low, meaning in herds of cows where the infection did not spread yet. In infected herds, vaccination should be done in all the animals or at least heifers. Vaccination of chronically infected cows prevents shedding of rickettsia through milk, constant or intermittent shedding. Vaccinated animals are considered not infected regardless to the specific antibody titer level. Vaccination does not aim only protection of the animals from infection, but also it eliminates shedding of Coxiella with milk $(2,13)$. Efficiency of the application of all control measures including vaccination should be estimated with application of serologic test and PCR methods by systematic sampling of blood, milk, vaginal mucus and feces. Application of vaccination has given a new concept to the suppression of this zoonozes not only in the service of public health but also for creating regions free of $Q$ fever in endemic regions(13).

After vaccination a problem of local reactions on the place of inoculation can appear, in sensitized animals and also in non sensitized ones as we have found in our research. In our study we did not detect rickettsia in milk samples from vaccinated cows 45 days after infection. Non vaccinated animals were continuously shedding rickettsia during the whole period of study. Today there are several vaccines at disposal for application in cows and sheep, such as bivalent vaccine C.burnetti and Ch.psittacci for sheep. Higher efficiency (300 times) was shown after vaccination with vaccines made of C.burnetii phase I, more virulent (has a complete LPS) then vaccine made of a virulent strains in phase II. Strains at disposal are usually Nine Mile strain, and rarely Henzerling strain for vaccine preparation. There are no unique programs for animal's vaccination; it is done related to the epidemiological situation in a certain region. Vaccination as a measure of prevention is used in Australia for sheep and humans exposed to the risk. In Russian federation vaccination is done in certain regions where $\mathrm{Q}$ fever appears endemically, where infection foci are present in the nature and in France and Slovakia, depending on the epidemiological 
situation in cows and sheep. Vaccination is a measure which will prevent the shedding of Coxiella and reduce the risk from spreading rickettsia, what will significantly reduce the risk of infection for humans. This does not mean that during the next year there will be no infections in humans, the disease can be eliminated but not eradicated $(2,13)$.

The aim of vaccination after the lambing season is to prevent new infections during the next lambing in young animals which are not pregnant. A two time vaccination before pregnancy reduces the risk from C.burnetii infection, majority of abortions are prevented and shedding of C.burnetii after the abortion would be reduced.

According to the literature data, a study on chemiotherapy application was done in infected animals. A possible recommendation for the prevention is usage of tetracycline in sheep, in dose $8 \mathrm{mg} / 1 \mathrm{~kg}$, in water, few weeks before lambing $(3,5)$.

General preventive measures that can be applied are the following: prohibition of movement, separation of the animals, prohibition of use of milk and wool, adequate hygiene measures, pest control, wearing of protective clothes, disinfection of equipment and vehicles, removal of placenta parts, adequate removal of manure (storage for 90 days in a roofed storage, afterwards it can be spread on the soil and plow), quarantine when calving and lambing and trade, avoid common grazing.

\section{PREVENTIVE MEASURES}

Control of Q fever in domestic animals and prevention of environment contamination with C.burnetii are the most important measures in protection of humans from infection (13). Other measures that can significantly reduce the risk from infection are: education of the residents in rural regions about the ways of infection, possible risks and precautions, education of farmers and other professionally exposed people with the aim of establishing a good agricultural practice. These actions can have influence on the reduction of risk for Q fever. Measures of self protection and zoo hygienic measures:

- Personal hygiene during and after working with animals

- Work clothing and shoes

- Use of protective gloves for the removal of postpartum products

- Additional equipment for self protection (mask, goggles) when in contact with materials with high risk (after abortions, during Q fever epidemics, when cleaning the objects for sheep, goat and cattle)

- Safe removal of placenta, aborted and stillbirth animals 
- Regular cleaning an disinfection during lambing or calving

- Rodent control and tick control

- Reduce the dust

- Use of quarantine when purchasing new animals

- Determine the causes of abortion and still birth

- Restrict entrance of people and other animals (including dogs and cats) whenever it is possible

Pregnant women, immunocompromised persons and persons with cardiovascular problems (especially if there is a valve failure) should avoid close contact with the animals, particularly during the partial season. It is recommended to use pasteurized milk and use of pasteurized milk for milk products (cheese). There should be a restriction order to objects or space which is of high risk for Q fever in humans and entrance should be allowed only to vaccinated humans.

Immunization of humans with a high risk occupation is a primary preventive step against $\mathrm{Q}$ fever (13). There is a certain risk from serious local reactions to vaccine in humans which were exposed to the infection or were vaccinated. That is why before vaccination it is important to:

- Check in anamnesis if the person had Q fever, or had clinical symptoms characteristic for $\mathrm{Q}$ fever or was vaccinated

- Analyze blood serum for the presence of antibodies against C.burnetii or

- Perform an intradermal test

Every positive result after screening preludes vaccination. Vaccination induces a solid immunity in majority of vaccinated individuals. Good communication on local and regional level and also cooperation between human and veterinary medicine is necessary because of the significance of this disease.

\section{EXPERIENCE FROM HOLLAND}

Publicity was informed about the event in Holland when there was a great Q fever epidemic registered in humans $(7,13)$. It all begun in 2005, and in the period from 2007-2009, the number of patients in one region was 3523 persons and for the whole period, more than 4000 patients for $\mathrm{Q}$ fever were found. During the epidemic, in $60 \%$ of patients the disease was found in asymptomatic form, $20 \%$ of patients were hospitalized and 7 people died (13). In the procedure of revelation the epizootiological background, abortions in goats were found in that region. It was proved that the goats were a source of infection. 
The following procedures were applied (7):

- all pregnant animals were removed from all infected farms

- all animals were examined with a serological ELISA test three times

- bulk samples of milk were examined by PCR method two times

- elimination of infected animals

- animals were vaccinated according to the age and size of the herd

- prohibited visitors

- prohibited use of milk

- application of biosafety measures

During this period 35000 pregnant animals were killed and costs were estimated for 6 million Euros. At the same period of time in neighboring countries Germany and Belgium, Q fever was found in humans and animals (13).

During the year 2010, European agency for food safety (EFSA) had an assignment to come out with measures for the estimation of risk factors and estimation of efficiency of measures for Q fever control in EU (13).

In Barcelona, 2011, a Second European meeting on Q fever was held where new scientific knowledge was discussed about epidemiology, pathogenesis, diagnostic methods and control measures for this important zoonozes.

Data in Europe after the epidemic in Holland show great variability in laboratory diagnostic methods that were used, criteria for explaining the results depending on the aim of diagnosis - herd screening, identification of animal that is shedding rickettsia, epidemiological research, and routine diagnostics. One of the conclusions of the Symposium was that professional knowledge is still insufficient, especially in epidemiology, identification of the ways of infection and of potential reservoirs. Regular veterinary surveillance of animals is necessary in order to track the infection and propose an accurate diagnosis in time. Based on the knowledge we have today, a key measure in $\mathrm{Q}$ fever control is vaccination of the animals with C.burnetii vaccine, phase I.

\section{AKNOWLEDGMENTS}

The presented work is part of the research done in the project TR31084 and 31071 granted by the Serbian Ministry of Education and Science 


\section{LITERATURA}

1. Arricau-Bouvery N., Souriau A., Bodier C., Dufour P., Rousset E., Rodolakis A.: Effect of vaccination with phase I and phase II Coxiella burnetii vaccines in pregnant goats. Vaccine, 23, 35, 4392-4402, 2005.

2. Behumer D.E., Biberstein E.L., Riemann H.P., Franti C.P., Sawyer M.: Q fever (Coxiella burnetii) Investigation in Dairy Cattle : Persistence of Antibodies After Vaccination. Am. J. Vet. Res., 36, 781-784, 1975.

3. Berri M.m Crochet D., Santiago S., Rodolakis A.: Spread of Coxiella burnetii infection in a flock of sheep after an episode of Q fever. Vet.rec., 157, 23, 737-740, 2005a.

4. Biberstin E.L., Behymer D.E., Bushnell R., Crenshaw G.,Riemann H.P., Franti C.E.: A survey of $\mathrm{Q}$ fever (Coxiella burnetii) in California Dairy Cows. Am J. Vet. Res. ; 35, 1577-1582, 1974.

5. Blain S.: Contagious diseases of ruminants: management of Q-fever in goats. Summa, Animali da Reddito, 2, 3, 59-63, 2007.

6. Korany M. Johnson KM. A survaey of Q fever antibodies in a high risk population in Panama. Am J Trop. Med Hyg, 29, 5,1007-11, 1980.

7. Karagiannis I., Schmmer B., van Lier A., Timen A., Schneeberger P., van Rotterdam B., de Bruin A., Wijkmans C., Rietveld A., van Duynhoven Y.: Investigation of a $Q$ fever outbreak in a rural area of the Nitherlands. Epidemiol. And Infect. 137, 9 1283-1294, 2009.

8. Macellaro A., Akesson A., Norlander L.: A survey of Q-fever in Sweden. Eur. J. Epidemiol, 9, 2, 213-6. 1993.

9. Rašeta B., Galić M., Šeguljev Z.: Q-groznica kod domaćih životinja u Vojvodini sa posebnim osvrtom na oboljenja ljudi. U: Zbornik radova, 4.Kongres mikrobiologa Jugoslavije, Beograd, 347, 1981,

10. Rašeta (Vidić) B., Mihajlović B.: Q-groznica kod domaćih životinja u SAP Vojvodini.Vet. glasnik, 27, 9, 695-703, 1983.

11. Rašeta(Vidić) B., Galić M., Pavlović R., Šeguljev Z.: Raširenost Q-groznice kod ovaca u Vojvodini. U: Zbornik radova, 25.Naučni sastanak mikrobiloga, epidemiologa i infektologa Jugoslavije, Pula, 299-301, 1983.

12. Schliesser Th., Schmidt U. : Zur Varbriatung und Bedeuting des Q-fibers bei Schaf und Rind. berisht. d. 8. kong. Dt. Vet. med. Gas., Berlin-Hamburg, 238-242. 1970.

13. Scientific opinion: Scientific Opinion on Q fever: EFSA journal, 8, 5, 1595, 2010.

14. Šeguljev Z., Vuković B., Stefanović S., Vidić B., Boboš S., Bačić M.: Izučavanje Q-groznice na farmama goveda u SAP Vojvodini.Vet. glasnik, 42, $11-12,729-733,1988$. 
15. Šeguljev Z., Vuković B., Vidić B., Bačić M.: Zoonoze u Vojvodini. U: Zbornik radova, Međunarodni Naučni skup Zaštite životne sredine i poljoprivrede, EKO'93, Novi Sad, 1993.

16. Šeguljev Z., Vidić B., Vuković B., Jerant-Patić V., Boboš S.: Rizik koji predstavlja infekcija izazvana sa C.burnetii za korisnike sirovog mleka u ishrani. Vet. glasnik, 48 , 3-4, 299-301, 1994.

17. Šeguljev Z., Vidić B., Šajgalik M.: The importance of sheep in the epidemiology of Q-fever in Vojvodina. Folia veterinaria, 41, 3-4, 107-111, 1997.

18. Vidić B., Boboš S., Lazić S., Bojović G.: Q-groznica u krava - imunoprofilaksa i njen uticaj na izlučivanje C.burnetii u mleku.Vet. glasnik, $44,1,27-$ $32,1990$.

19. Vidić B., Mihajlović B., Galić M., Pavlović R., Boboš S.: Findings of antibodies for C.burnetti with cows having clinical indications of Q-fever. Acta Vet. $40,1,(27-30), 1990$.

20. Vidić B., Boboš S., Lazić S., Grgić Ž., Hristovski M., Zorić M.: Q-Fever (Coxiella burnetii)in cows with reproductive disorders. 1-7 Mac.Vet. Review, 24, 1-2 1-7, 1995.

21. Vidić B., Šeguljev Z., Vuković B., Grgić Ž.: Importance of sheep in epidemiology od Q-Fever. Mac. Vet. Review, 25, 1-2, 1996.

22. Vidić B., Boboš S., Grgić Ž., Orlić D., Bugarski D.: Sheddings of Coxiella burnetii through milk and its influence on the mammary gland. In: Proceedings, 1.Middle-European Congress for buiatrics, Balatonfured, Hungary, 316-322. 1999.

23. Vidić B., Bjelajac B., Šeguljev Z.: Q-grounica: epizootiologija, dijagnostika i kontrola = Q-fever: epizootiologija, diagnostic and control. Vet. žurnal Republike Srpske, 1, 1/2, 38-42, 2001.

24. Vidić B., Šeguljev Z., Grgić Ž., Savić-Jevdenić S.: Seroepidemiology of Q-fever in sheep.In: Microbiologia Balkanica, 3nd Balkan Confrence of Microbiology, Istanbul, Turkish Microbiological Society, 460, 2003.

25. Vidić B., Ašanin R., Boboš S., Bugarski D.: Q-fever (Coxiella burneti) investigations in dairy cows. In: Prvi Simpozijum o zoonozama sa medunarodnim učešćem, Sarajevo, Udruženje mikrobiologa BiH, 62. 2005.

Received / Primljeno: 15.08.2013. Accepted / Odobreno: 08.12.2013. 